\title{
Undesirable import to Japan
}

Tokyo

WITH Japan under pressure to increase imports of US goods, it is ironical that one product Japan imports freely from the United States may have brought acquired immune deficiency syndrome (AIDS). According to last month's Taisha, the Japanese medical journal, two now-dead Japanese haemophiliacs were killed by AIDS, probably by infected blood plasma, almost certainly imported from the United States.

One of the victims, aged 48, died in July 1983 and the other in November last year, aged 62 . The victims, the first from AIDS in Japan, showed an extraordinary loss of immunity, and the presence of antibodies to the virus HTLV-III has been confirmed.

No cases of AIDS have yet been reported among Japan's homosexual community, but a confirmed Japanese homosexual now living in the United States who returned to Japan in mid-January was diagnosed as an AIDS sufferer. The AIDS Research and Study Committee of the Health and Welfare Ministry says there is little chance that the man infected others in Japan.

The emergence of AIDS cases among Japanese haemophiliacs seems to be attributable to Japan's almost insatiable demand for US blood plasma. Despite one of the highest rates of blood donation in the world, Japan depends on the United States for nearly 90 per cent of the plasma it consumes, amounting to 300,000 litres a year. Demand for plasma-protein fractions and blood-component preparations is rising, for the latter by 15 per cent a year.

So why is Japan so dependent on blood plasma imports when there were more than eight million blood donations last year? Officials at the Health and Welfare Ministry explain that donors in Japan give only $200 \mathrm{ml}$ of blood on each occasion, compared with about $400 \mathrm{ml}$ in other countries. But a Japan Red Cross official says that in the United States in 1982, just under six million donations of about 450 $\mathrm{ml}$ were made, suggesting that per capita blood donation in the two countries is similar.

Dependency on blood imports is in part a legacy of the system before 1982 . Blood donations were then saved almost exclusively for the use of the donor himself, who would resist the idea of volunteering blood for others, probably for the reasons that also make Japanese reluctant to donate organs for transplant (see Nature 313, 338; 1985).

The Health and Welfare Ministry's planned solution of this vexing problem is threefold. First, Japanese donors will be asked to donate $400 \mathrm{ml}$ instead of the present $200 \mathrm{ml}$. Second, plasmaphoresis, which separates the plasma and returns red cells to the donor, will be more widely used. Third, doctors will be asked to avoid un- necessary wastage of plasma. In the meantime, however, imports will continue and there are no plans to screen imported blood for AIDS.

All of this must provide small comfort for Japan's haemophiliacs. The article in Taisha even reports that the blood of 23 out of a random sample of 50 Japanese haemophiliacs contained antibodies to the virus HTLV-III, which suggests that a large proportion of Japan's 5,000 haemophiliacs may have already been exposed.

Even if imports stopped, there would be

another danger. Drs Kazuo Ohkouchi and Hiroyuki Sato of Kyushu University in southern Japan have now shown that the virus HTLV-I, which causes adult T-cell leukaemia (ATL), can be transmitted by blood transfusion. ATL is endemic in southern Japan, where approximately 20,000 carriers are found among blood donors each year. Dr R.C. Gallo, chief of the tumour cell laboratory at the US National Cancer Institute, has even suggested that an AIDS-like epidemic of ATL may be imminent. Clearly, the management of blood supplies in Japan is a matter that in future will come under increasing scrutiny by the eyes of the world.

David Swinbanks

\section{ESA, Japan agree on participation in planned US space station}

EUROPE formally agreed last week to join the United States in the development of a space station, but details such as who spends how much on what remain to be decided. The European Space Agency (ESA) will now sign a memorandum of understanding with the National Aeronautics and Space Administration (NASA) which requires that the design of the space station, with costs and commitments, must be ready by the end of 1986. This phase of the work will cost ESA $\$ 65$ million.

NASA has already signed a similar agreement with Canada, which aims to provide robot-servicing equipment at a cost of some hundreds of millions of dollars, and is due to sign another with Japan this month (see above).

The European contribution may finally be some $\$ 2,000$ million, which should buy a pressurized module that could be used as a manned laboratory (called Columbus), a number of free-flying payload carriers for both low-inclination and polar orbits, a servicing vehicle and a resources module that could provide both the pressurized module and the payload carriers with electric power, cooling and stabilizing systems.

These housekeeping elements have been included in ESA's plan at French insistence, and would enable the European modules to fly separately from the US space station if necessary, although (for the moment) Europe would still have to rely on the US space shuttle to put its astronauts into orbit. France, however, has plans for a mini-shuttle (Hermes) and in Britain, British Aerospace has described the concept of a horizontal take-off and landing spacecraft (HOTOL). Either of these could ultimately provide people with independent access to space.

There are more immediate issues still to be resolved. US fears that technologies transferred to Europe would leak to the Soviet Union engender corresponding European fears about access to US science, technology and data. There are also the issues of who pays the still unknown ○)1985 Nature Publishing Group maintenance and running costs of the station, the legal framework for deciding patent rights arising from work on the station and the management and decision-making structure of the enterprise.

Robert Walgate

Tokyo

JAPAN has decided to take part in the US project to build a manned space station. James Beggs, head of the US National Aeronautics Space Administration (NASA), who has made earlier trips to Japan to promote the space station, will return to Tokyo for the signing on 9 May of an agreement between NASA and Japan's Science and Technology Agency (STA).

The initial agreement will cover a twoyear period of design work and will provide Japan with technical information on the space station. STA is refusing to release details of the budget until after the signing, but it is known that some 1,400 million yen ( $\$ 5.6$ million) has been earmarked for the project in this year's budget.

Informally, a consensus seems to have been reached that Japan should take the opportunity to master new technology and build one whole experimental module of the space station. A subcommittee of STA's Space Development Committee has recommended that it consist of three parts: a pressurized cabin ten metres long and four metres in diameter for use in experiments on new materials and new pharmaceuticals more easily produced in gravityfree conditions, a service platform for testing of telecommunications equipment in outer space and a storage cabin. Total design and construction expenses are likely to exceed Y200-300 thousand million million ( $\$ 800$ million).

Industry has already expressed considerable interest in the space station and several large corporations, including Mitsubishi, Mitsui, Sumitomo and Fuyo, are now merging their respective study groups to find the best way to win commercial advantage from the station. Alun Anderson 